Jurnal Perikanan (2019) Volume 9. No. 1 : 101-111

DOI : https://doi.org/10.29303/jp.v8i2.138

\title{
PENGARUH KOMBINASI HASIL FERMENTASI AMPAS TAHU DAN DEDAK TERHADAP PERTUMBUHAN POPULASI Daphnia sp.
}

\section{THE EFFECT OH THE COMBINATION TOFU AND BRAN FERMENTATION ON THE GROWTH OH THE POPULATION Daphnia sp.}

\author{
Fuji Zakiyah $^{1 *}$ ), Nanda Diniarti $\left.{ }^{1}\right)$, Bagus Dwi Hari Setyono ${ }^{1}$ ) \\ ${ }^{1)}$ Program Studi Budidaya Perairan, Universitas Mataram \\ Jl. Pendidikan No, 37 Mataram, NTB
}

\begin{abstract}
Abstrak
Daphnia sp. adalah krustasea berukuran kecil yang sering disebut sebagai kutu air dan hidup di perairan tawar. Daphnia sp. merupakan salah satu pakan alami untuk larva ikan air yang memiliki kelebihan yaitu mudah dicerna, ukurannya sesuai dengan bukaan mulut, memiliki kandungan nutrisi yang tinggi, memiliki kandungan asam amino esensial yang tinggi dan dapat dibudidayakan secara massal. Bahan organik ampas tahu dan dedak yang difermentasi dengan bakteri probiotik diharapkan dapat meningkatkan efisiensi pemanfaatan pakan dan pertumbuhan Daphnia sp. Penelitian ini bertujuan untuk mengetahui pengaruh kombinasi hasil fermentasi ampas tahu dan dedak terhadap populasi dan menentukan kombinasi pakan terbaik dengan hasil fermentasi ampas tahu dan dedak yang menghasilkan pertumbuhan Daphnia sp. yang tinggi. Penelitian ini menggunakan Rancangan Acak Lengkap (RAL) yang terdiri dari 4 perlakuan dan 3 kali ulangan sehingga memperoleh 12 unit percobaan. Perlakuan A kontrol (pemberian pakan komersil), perlakuan B (pemberian 0,15 g/l ampas tahu dan 0,3 gl dedak), perlakuan $\mathrm{C}$ (pemberian 0,3 g/l ampas tahu), dan perlakuan D (pemberian 0,6 g/l dedak). Hasil penelitian ini menunjukkan bahwa pemberian bahan organik ampas tahu dan dedak melalui proses fermentasi probiotik berpengaruh terhadap kepadatan populasi, laju pertumbuhan populasi, dan produksi biomassa Daphnia sp. Perlakuan B merupakan perlakuan paling baik yaitu dengan kepadatan populasi tertinggi sebesar 246,67 ind/l, laju pertumbuhan populasi sebesar 5,199\%/hari, dan produksi biomassa sebesar $340 \mathrm{mg} / 1$.
\end{abstract}

Kata Kunci : Daphnia sp., ampas tahu, dedak, fermentasi, pertumbuhan

\begin{abstract}
Abtrack
Daphnia sp. is an animal Crustacea which is often referred to as small-sized water lice that live in freshwater and is one of the natural feeds for aquatic larvae which are easily digested, their size is in accordance with mouth openings, has high nutrient content, contains essential amino acids which high and can be cultivated in bulk. Tofu pulp and bran organic fermented with probiotic bacteria are expected to increase the efficiency of feed utilization and growth of Daphnia sp. This study aims to determine the effect of the combination of tofu and bran fermentation results on the population and determine the best combination of feed with tofu pulp and bran fermentation which results in high growth of Daphnia sp. This study used a Completely Randomized Design (CRD) consisting of 4 treatments and 3 replications to obtain 12 experimental units. Treatment A: control (commercial feeding), treatment B (giving $0.15 \mathrm{~g} / 1$ tofu dregs and $0.3 \mathrm{gl}$ bran), treatment $\mathrm{C}$ (giving $0.3 \mathrm{~g} / 1$ tofu dregs), and *Korespondensi :

evinurquranniah@yahoo.com
\end{abstract}


Jurnal Perikanan (2019) Volume 9. No. 1 : 101-111

DOI : https://doi.org/10.29303/jp.v8i2.138

treatment D (giving $0,6 \mathrm{~g} / 1$ bran). The results of this study indicate that the administration of tofu pulp and bran through the probiotic fermentation process affects population density, population growth rate, and biomass production of Daphnia sp. Treatment B is the best treatment with the highest population density of 246.67 ind / 1, population growth rate of $5.199 \%$ / day, and biomass production of $340 \mathrm{mg} / 1$.

Keywords: Daphnia sp., tofu, bran, fermentation, growth

\section{Pendahuluan}

Daphnia sp. adalah krustasea berukuran kecil atau sering disebut dengan kutu air yang hidup di perairan tawar. Hewan tersebut merupakan salah satu jenis pakan alami yang potensial dikembangkan untuk kegiatan pembenihan ikan air tawar. Keunggulan Daphnia sp. sebagai pakan alami antara lain mudah dicerna, ukurannya sesuai dengan bukaan mulut larva, memiliki kandungan nutrisi yang tinggi, memiliki kandungan asam amino esensial yang tinggi, pemberian pada media budidaya tidak menurunkan kualitas air, serta dapat dibudidayakan secara massal (Rachman, 2012).

Pengembangan Daphnia sp. melalui budidaya tidak terlepas dari peranan pakan dan kualitas media (lingkungan) budidaya. Pakan yang diberikan biasanya berupa bahan anorganik, organik (kotoran ternak), fitoplankton (Chlorella sp.), atau bakteri. Pertumbuhan Daphnia sp. memerlukan nutrisi yang baik, yaitu berasal dari bahan organik tersuspensi dan bakteri yang diperoleh dari pupuk yang ditambahkan ke dalam media kultur. Bahan organik dapat diperoleh dari limbah industri kecil pangan.

Limbah industri kecil yang terdapat di Kota Mataram antara lain ampas tahu dan dedak. Ampas tahu merupakan salah satu limbah organik yang mudah didapatkan karena jumlah produksinya cukup besar dan diperkirakan masih banyak mengandung unsur hara. Ampas tahu dapat dimanfaatkan sebagai pakan ataupun pupuk yang bernutrisi cukup tinggi, karena memiliki kandungan protein kasar sebesar 27,55\% (Nuraini, 2009). Dedak padi merupakan salah satu limbah pertanian yang keberadaannya cukup banyak dan mudah didapatkan serta harganya relatif murah menjadi salah satu pertimbangan penggunaannya sebagai sumber bahan pakan.

Bahan organik yang memiliki kandungan nutrisi protein, lemak dan karbohidrat dapat dimanfaatkan oleh bakteri melalui perombakan bahan organik dalam ketersediaan pakan untuk mendukung pertumbuhan Daphnia sp. Bahan organik dirombak melalui proses fermentasi bakteri probiotik. Proses fermentasi bahan pakan oleh mikroorganisme menyebabkan perubahanperubahan yang menguntungkan seperti memperbaiki mutu bahan pakan, baik dari segi aspek gizi maupun daya cerna serta meningkatkan daya simpannya (Bidura, 2007 dalam Setiawan, 2017).

Pemanfaatan bahan organik sebagai sumber nutrisi dalam suatu budidaya Daphnia sp. menjadi salah satu pertimbangan pemanfaatan bahan organik seperti pada penelitian sebelumnya bahan organik kotoran ayam (Sulasingkin, 2003), bekatul (Mubarak, 2009), serta bungkil kelapa (Arief, 2012) sering digunakan sebagai sumber nutrisi Daphnia sp. dan mampu meningkatkan pertumbuhannya. Pemanfaatan bahan organik ampas tahu dan dedak juga sangat cocok digunakan sebagai sumber nutrisi yang diketahui memiliki kandungan nutrisi yang tinggi yang untuk meningkatkan pertumbuhan Daphnia sp. Oleh karena itu, perlunya penelitian dalam penggunaan bahan organik ampas tahu dan dedak yang dikombinasikan menjadi suatu pakan yang baru dan diharapkan mampu meningkatkan kepadatan serta laju pertumbuhan populasi Daphnia sp. yang terbaik. 
Tujuan dari penelitian ini adalah untuk mengetahui kombinasi hasil fermentasi ampas tahu dan dedak terhadap populasi Daphnia sp. dan menentukan kombinasi pakan terbaik dengan hasil fermentasi ampas tahu dan dedak yang menghasilkan pertumbuhan Daphnia sp. yang tinggi.

\section{Metode Penelitian}

Kegiatan penelitian ini dilaksanakan pada bulan 5 Desember 2018 - 9 Januari 2019 di Laboratorium Basah Program Studi Budidaya Perairan. Uji C/N ratio pada Laboratorium Analitik Fakultas MIPA. Pengamatan jumlah koloni bakteri di Laboratorium Mikrobiologi Fakultas Pertanian Unversitas Mataram.

\section{Rancangan Penelitian}

Penelitian ini menggunakan Rancangan Acak Lengkap (RAL) dengan 4 perlakuan dan 3 ulangan. Penentuan dosis bahan organik ampas tahu dan dedak ditentukan berdasarkan jumlah protein yang terkandung di dalam ampas tahu dan dedak. Jumlah protein ampas tahu 28\% dan dedak 14\%. Masing-masing dosis yang digunakan sebanyak $0,3 \mathrm{~g} / \mathrm{l}$ ampas tahu (Nainggolan, 2017) dan 0,6 g/l dedak (Nasution, 2014). Pemberian jumlah dosis tersebut diberikan per 2 liter. Kombinasi pakan fermentasi yang menjadi perlakuan adalah A. Pemberian pakan komersil (kontrol), B. Pemberian 0,15 g/l ampas tahu dan 0,3 g/l dedak, C. Pemberian 0,3 $\mathrm{g} / \mathrm{l}$ ampas tahu, D. Pemberian 0,6 g/l dedak.

\section{Fermentasi Ampas Tahu dan Dedak}

Proses fermentasi diawali dengan ampas tahu dan dedak yang sudah kering ditimbang sesuai dengan dosis yang sudah ditentukan, selanjutnya ditambahkan dengan bakteri probiotik EM4 (untuk perikanan dan tambak). Bakteri probiotik EM4 yang sebelumnya sudah diaktivasi dengan molase dengan perbandingan 1:1 ke dalam $100 \mathrm{ml}$ air. Dilakukan pencampuran ampas tahu dan dedak ke dalam gelas yang berisi probiotik EM4 dan molase kemudian diaduk hingga tercampur rata. Hasil pencampuran tersebut ditutup rapat menggunakan plastik dan diikat agar udara dari luar tidak masuk serta didiamkan selama 1 minggu.

\section{Penghitungan Kepadatan Daphnia sp.} Perhitungan populasi Daphnia sp. dilakukan setiap dua hari sekali menggunakan gelas ukur. Sebanyak 100 $\mathrm{ml}$ air diambil secara homogen, kemudian dituangkan kedalam cawan petri untuk dilakukan perhitungan. Homogenisasi dilakukan dengan cara mengaduk media kultur meggunakan selang aerasi. Perhitungan dilakukan secara manual dengan menggunakan pipet tetes dan cawan petri. Hasil perhitungan kemudian dikonversikan ke dalam satuan liter (Yunda, 2015).

\section{Analisis Data}

Parameter diuji secara statistik adalah kepadatan populasi; laju pertumbuhan populasi; produksi biomassa. Pengaruh hasil fermentasi ampas tahu dan dedak terhadap setiap parameter ditentukan dengan menggunakan ANOVA (Analysis of Variance) pada taraf 5\%. Apabila terdapat pengaruh yang berbeda nyata, maka dilakukan uji lanjut dengan uji Beda Nyata Terkecil (BNT).

\section{Hasil Penelitian}

\section{Pola Pertumbuhan Populasi Daphnia sp.} Pengamatan terhadap pola pertumbuhan populasi Daphnia sp. dilakukan selama 12 hari dengan periode perhitungan selang 2 hari sekali. Berdasarkan grafik pola pertumbuhan populasi Daphnia sp. selama penelitian menggunakan hasil fermentasi ampas tahu dan dedak dengan dosis yang berbeda menunjukkan hasil dari setiap perlakuan membentuk kurva sigmoid yang terdiri dari fase lag, fase log (eksponensial), fase stasioner dan fase kematian. Pola 
pertumbuhan populasi Daphnia sp. dapat diihat pada Gambar 1.

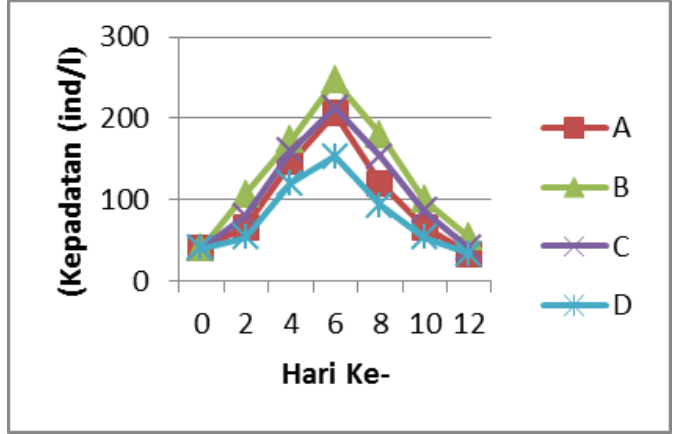

Gambar 1. Pola Pertumbuhan Populasi Daphnia sp.

\section{Kepadatan Populasi}

Kepadatan populasi Daphnia sp. yang masing-masing diberikan perlakuan fermentasi ampas tahu dan dedak dengan dosis yang berbeda-beda memperlihatkan bahwa kepadatan populasi tertinggi pada semua perlakuan dicapai pada hari ke-6. Dalam pelaksanaan penelitian ini, pemberian kombinasi fermentasi ampas tahu $(0,15 \mathrm{~g} / \mathrm{l})$ dan dedak $(0,3 \mathrm{~g} / \mathrm{l})$ pada perlakuan B menghasilkan kepadatan tertinggi yaitu 246,67 ind/l. Urutan berikutnya yaitu pada perlakuan $\mathrm{C}(0,3 \mathrm{~g} / 1$ ampas tahu) sebesar 213,33 ind $/ 1$, perlakuan A (pakan komersil) sebesar 206,67 ind/1 dan kepadatan terendah pada perlakuan $\mathrm{D}$ yang diberikan fermentasi dedak $(0,6 \mathrm{~g} / \mathrm{l})$ yaitu 153,33 ind $/ 1$. Kepadatan populasi Daphnia sp. dapat dilihat pada Gambar 2.

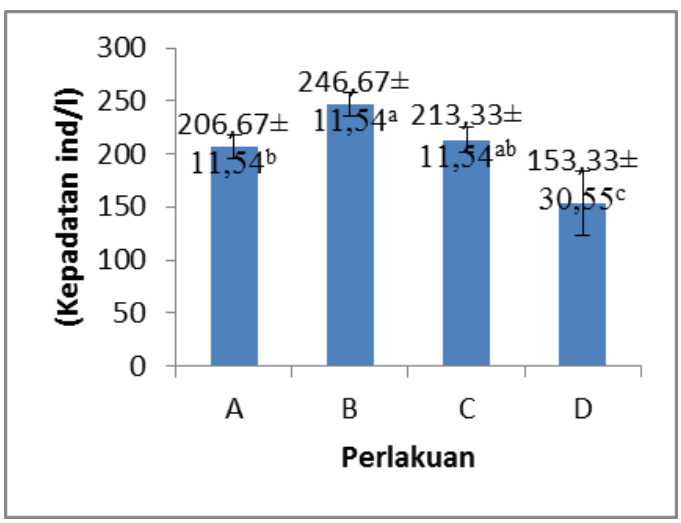

Gambar 2. Diagram Kepadatan Populasi Tertinggi Daphnia sp.

\section{Laju Pertumbuhan Populasi}

Laju pertumbuhan populasi Daphnia sp. terjadi pada hari ke-6. Nilai tertinggi terdapat pada perlakuan B yaitu $5,199 \% /$ hari, kemudian perlakuan $\mathrm{C}$ yaitu $5,054 \%$ /hari, perlakuan A yaitu $5,022 \% /$ hari dan nilai terendah terdapat pada perlakuan D yaitu $4,711 \% /$ hari. Hasil analisis sidik ragam menunjukkan bahwa pemberian bahan organik ampas tahu dan dedak melalui proses fermentasi bakteri probiotik memberikan pengaruh yang nyata dengan nilai $\mathrm{F}$ hitung $>\mathrm{F}$ tabel $(\mathrm{P}>0,05)$ terhadap laju pertumbuhan populasi Daphnia sp. Berdasarkan uji lanjut LSD, pelakuan B $\left(5,199 \pm 0,046^{\mathrm{a}}\right)$ tidak berbeda nyata dengan perlakuan $\mathrm{C}$ $\left(5,054 \pm 0,055^{\mathrm{a}}\right)$ dan perlakuan A $\left(5,022 \pm 0,055^{\mathrm{a}}\right)$ tetapi pelakuan B $\left(5,199 \pm 0,046^{\mathrm{a}}\right)$ berbeda nyata dengan perlakuan D $\left(4,771 \pm 0,208^{b}\right)$. Perlakuan C $\left(5,054 \pm 0,05^{\mathrm{a}}\right)$ tidak berbeda nyata dengan perlakuan A $\left(5,022 \pm 0,055^{\mathrm{a}}\right)$ dan perlakuan B $\left(5,199 \pm 0,046^{\mathrm{a}}\right) . \quad$ Perlakuan A $\left(5,022 \pm 0,055^{\mathrm{a}}\right)$ berbeda nyata dengan perlakuan D $\left(4,771 \pm 0,208^{\mathrm{b}}\right)$. Laju pertumbuhan populasi Daphnia sp. dapat dilihat pada Gambar 3.

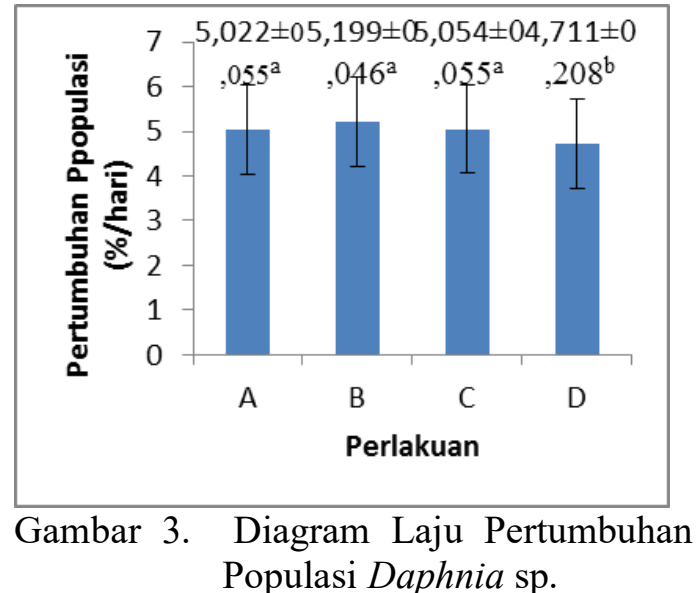

\section{Produksi Biomassa}

Berdasarkan hasil penelitian yang dilakukan didapatkan hasil bobot biomassa 
Daphnia sp. selama pemeliharaan dalam berat basah dengan biomassa tertinggi pada perlakuan B yaitu $340 \mathrm{mg} / \mathrm{l}$, perlakuan $\mathrm{C}$ yaitu $313,33 \mathrm{mg} / \mathrm{l}$, perlakuan D yaitu $300 \mathrm{mg} / 1$ dan biomassa terendah pada perlakuan A yaitu 256,67 mg/l. produksi biomassa Daphnia sp. dapat dilihat pada Gambar 4.

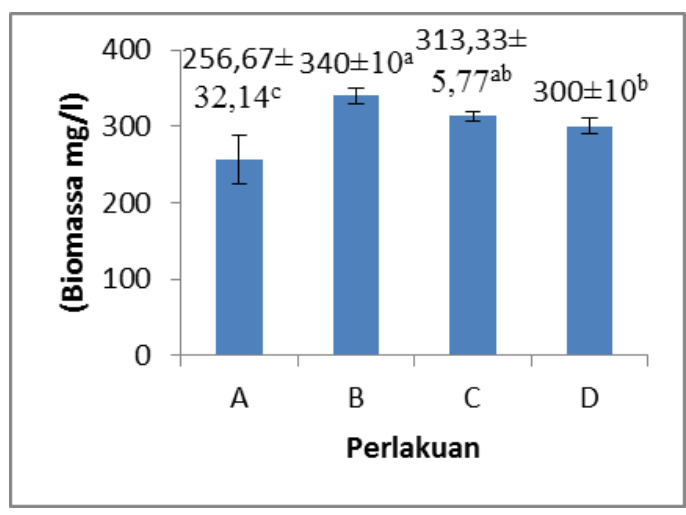

Gambar 4. Diagram Produksi Biomassa Daphnia sp.

Berdasarkan hasil analisis sidik ragam menunjukkan bahwa pemberian bahan organik ampas tahu dan dedak melalui proses fermentasi bakteri probiotik memberikan pengaruh nyata dengan $\mathrm{F}$ hitung $>\mathrm{F}$ tabel $(\mathrm{P}>0,05)$ terhadap produksi biomassa Daphnia sp. Berdasarkan hasil uji lanjut LSD, perlakuan B $\left(340 \pm 10^{\mathrm{a}}\right)$ tidak berbeda nyata dengan perlakuan $C\left(313,33 \pm 5,77^{\mathrm{ab}}\right)$ dan perlakuan D $\left(300 \pm 10^{\mathrm{b}}\right)$. Perlakuan C $\left(313,33 \pm 5,77^{\mathrm{ab}}\right)$ tidak berbeda nyata dengan perlakuan D $\left(300 \pm 10^{\mathrm{b}}\right)$ tapi berbeda nyata dengan perlakuan A $\left(256,67 \pm 32,14^{c}\right)$. Perlakuan B $\left(1020 \pm 10^{\mathrm{a}}\right)$ berbeda nyata dengan perlakuan A $\left(256,67 \pm 32,14^{c}\right)$.

\section{Analisis $\mathbf{C} / \mathbf{N}$ rasio}

Berdasakan hasil uji Laboratorium kandungan bahan organik media kultur Daphnia sp. dapat dilihat pada Tabel 1 dan Tabel 2. Berdasarkan hasil laboratorium kandungan hara media kultur Daphnia sp. kandungan $\mathrm{N}$ organik tertinggi pada pakan komersil sebanyak $4,68 \%$, pada ampas tahu sebanyak $2,74 \%$ dan dedak sebanyak $0,69 \%$. Total $\mathrm{C}$ organik tertinggi pada pakan komersil sebanyak $42,07 \%$, dedak sebanyak $38,47 \%$ dan ampas tahu sebanyak 37,95\%. Kandungan $\mathrm{C} / \mathrm{N}$ ratio tertinggi pada bahan organik dedak sebanyak 56:1, ampas tahu sebanyak 14:1 dan pakan komersil sebanyak 9:1.

\section{Perhitungan Jumlah Bakteri}

Berdasarkan hasil pengamatan Laboratorium Mikrobiologi pengamatan jumlah koloni bakteri dapat dilihat pada Tabel 3. Dari hasil pengamatan jumlah bakteri didapatkan bahwa jumlah bakteri dalam fermentasi ampas tahu dan dedak (perlakuan B) sebesar 1,305 × $10^{10} \mathrm{CFU}$, ampas tahu (perlakuan $\mathrm{C}$ ) jumlah bakteri sebesar $13,08 \times 10^{7} \mathrm{CFU}$, sedangkan pada dedak (perlakuan D) jumlah bakteri sebesar 9,92 × $10^{9}$ CFU. Tingginya bahan organik dalam media pemeliharaan akan meningkatakan jumlah bakteri dan partikel organik hasil dekomposisi oleh bakteri sehingga dapat meningkatkan jumlah makanan pada media sehingga dapat mempengaruhi pertumbuhan populasi dan biomassa Daphnia sp. Tabel 1. Analisis N

\begin{tabular}{llccccc} 
No. & Kode Sampel & $\begin{array}{c}\text { Massa } \\
\text { Sampel } \\
\text { (gram) }\end{array}$ & $\begin{array}{c}\text { Titrasi } \\
\text { Sampel } \\
(\mathbf{m l})\end{array}$ & $\begin{array}{c}\text { Titrasi } \\
\text { Blanko } \\
(\mathbf{m l})\end{array}$ & $\begin{array}{c}\mathbf{N ~ H}_{2} \mathbf{S O}_{4} \\
\text { Penitar }\end{array}$ & \% N \\
\hline 1. & Ampas Tahu & 0,0179 & 0,50 & 0,15 & 0,1 & 2,74 \\
2. & Dedak & 0,0510 & 0,40 & 0,15 & 0,1 & 0,69 \\
3. & Pakan Komersil & 0,0374 & 1,40 & 0,15 & 0,1 & 4,68 \\
\hline
\end{tabular}

Sumber: Hasil Uji Kjeldhal Kandungan N di Laboratorium Analitik Fakultas MIPA (2018)

Tabel 2. Analisis C 
Jurnal Perikanan (2019) Volume 9. No. $1: 101-111$

DOI : https://doi.org/10.29303/jp.v8i2.138

\begin{tabular}{llccccc} 
No. & Kode Sampel & $\begin{array}{c}\text { Massa } \\
\text { Sampel } \\
\text { (gram) }\end{array}$ & $\begin{array}{c}\text { Absorben } \\
\text { Sampel }\end{array}$ & $\begin{array}{c}\text { Absorben } \\
\text { Blanko } \\
\text { (ml) }\end{array}$ & $\begin{array}{c}\text { Pengenceran } \\
\text { Sampel }\end{array}$ & $\%$ C \\
\hline 1. & Ampas Tahu & 0,0107 & 0,054 & 0 & 100 & 37,95 \\
2. & Dedak & 0,0132 & 0,065 & 0 & 100 & 38,47 \\
3. & Pakan Komersil & 0,0104 & 0,056 & 0 & 100 & 42,07 \\
\hline
\end{tabular}

Sumber : Hasil Uji Spectrometri Kandungan C di Laboratorium Analitik Fakultas MIPA (2018)

Tabel 3. Perhitungan Jumlah Koloni Bakteri

\begin{tabular}{lccc}
\hline \multicolumn{1}{c}{ Perlakuan } & Kode Isolat & Rata- Rata & Jumlah Bakteri (CFU) \\
\hline B (ampas tahu dan dedak) & $10^{-7}$ & 130,5 & $1,305 \times 10^{10}$ \\
C (ampas tahu) & $10^{-7}$ & 1,308 & $13,08 \times 10^{7}$ \\
D (dedak) & $10^{-7}$ & 992 & $9,92 \times 10^{9}$ \\
\hline
\end{tabular}

Tabel 4. Pengukuran Kualitas Air

\begin{tabular}{|c|c|c|c|c|c|}
\hline \multirow[t]{2}{*}{ Parameter } & \multicolumn{4}{|c|}{ Perlakuan } & \multirow{2}{*}{ Referensi } \\
\hline & $\mathbf{A}$ & B & $\mathrm{C}$ & D & \\
\hline Suhu $\left({ }^{0} \mathrm{C}\right)$ & 30 & $29,7-30$ & $29,9-30$ & 30 & $\begin{array}{l}25 \text { - } 30 \text { (Mubarak et al., } \\
2009)\end{array}$ \\
\hline $\mathrm{DO}(\mathrm{mg} / \mathrm{l})$ & $5,2-5,9$ & $5,4-5,8$ & $4,8-5,8$ & $4,2-5,9$ & $0,34-7,7$ (Purba, 2003) \\
\hline $\mathrm{pH}$ & $7-7,6$ & $7-7,8$ & $7-7,6$ & $7-7,6$ & $\begin{array}{l}\text { 6,5 -8,6 Pennak (1989) } \\
\text { dalam Sulasingkin (2003) }\end{array}$ \\
\hline
\end{tabular}

\section{Pembahasan}

Pola Pertumbuhan Populasi Daphnia sp. Pola pertumbuhan populasi Daphnia sp. menunjukkan kurva sigmoid yang terdiri dari fase lag, fase eksponensial, fase adaptasi dan fase kematian. Fase adaptasi (lag) terjadi pada hari ke-0, dimana pada fase ini ditandai dengan tidak adanya penggandaan diri. Suprimantoro et al. (2016) menyatakan bahwa, fase lag merupakan fase dimana Daphnia sp. melakukan penyusuaian diri terhadap media kultur. Fase log (eksponensial) terjadi dari hari ke-1 sampai hari ke-5, hal ini ditandai dengan terjadinya peningkatan jumlah individu Daphnia sp. menjadi beberapa kali lipat dalam waktu tertentu. Menurut Mokoginta (2003), peningkatan jumlah populasi Daphnia sp. terjadi karena adanya proes reproduksi secara phartenogenesis yang berlangsung pada kondisi lingkungan media kultur yang subur. Fase stasioner pada penelitian ini terjadi pada hari ke-6 yaitu dengan kepadatan yang tertinggi yaitu pada perlakuan B dengan rata-rata kepadatan populasi Daphnia sp. mencapai $243 \mathrm{ind} / 1$. Fase kematian terjadi pada hari ke-8 sampai hari ke-12 hal ini dikarenakan pakan yang tersedia pada media kultur tidak dapat mencukupi kebutuhan bagi Daphnia sp. yang sangat melimpah

\section{Kepadatan Populasi Daphnia sp.}

Pada perlakuan B tingkat pemanfaatan pakan yang dikonsumsi oleh Daphnia sp. dapat mempengaruhi pertumbuhan dan kelimpahannya. Kandungan nutrisi dalam media pemeliharaan berpengaruh dalam ketersediaan jumlah pakan yang dibutuhkan dalam bereproduksi. Menurut Zahidah (2012), kondisi pakan yang cukup untuk Daphnia sp. muda dapat mempengaruhi pertumbuhan dan pergantian kulit (molting) Daphnia sp. menjadi indivdu dewasa dan dapat bereproduksi secara parthenogenesis, 
Jurnal Perikanan (2019) Volume 9. No. 1 : 101-111

DOI : https://doi.org/10.29303/jp.v8i2.138

sehingga terjadi penambahan individu menjadi beberapa kali lipat.

Perlakuan C (ampas tahu) dan perlakuan A (pakan komersil) menunjukkan kepadatan tertingi dan jumlah kepadatannya tidak berbeda nyata dengan perlakuan B. Hal ini disebabkan karena pakan yang terkandung di dalam media pemeliharaan dapat dimafaatkan dengan baik oleh Daphnia sp. sehingga pertumbuhan Daphnia sp. dapat tercukupi. Rendahnya kepadatan populais pada perlakuan D, Hal ini terjadi karena kandungan nutrisi yang terkandung di dalam media pemeliharaan tidak dapat memenuhi ketersediaan pakan pada media pemeliharaan sehingga terjadi persaingan makanan dan mengakibatkan jumlahnya lebih sedikit.

\section{Laju Pertumbuhan Populasi Daphnia sp.} Berdasarkan hasil penelitian didapkatkan laju pertumbuhan populasi Daphnia sp. tertinggi terjadi pada hari ke-6, perlakuan yang memiliki nilai petumbuhan yang tinggi yaitu pada perlakuan $B$, namun tidak berbeda nyata dengan perlakuan $\mathrm{C}$ dan A. Hal ini disebabkan karena jumlah $\mathrm{C} / \mathrm{N}$ rasio pada perlakuan $\mathrm{B}$ dan $\mathrm{C}$ tinggi sedangkan pada perlakuan $\mathrm{A}$ jumlah $\mathrm{C} / \mathrm{N}$ rasio rendah. Artinya semakin rendah $\mathrm{C} / \mathrm{N}$ rasio maka kandungan $\mathrm{N}$ semakin tinggi. Kebutuhan akan karbon dan nitrogen yang optimal 30:1 hingga 40:1 dimana dalam metabolisme hidup mikroorganisme memanfaatkan sekitar 30 bagian dari karbon untuk masing-masing bagian dari nitrogen. Protein yang tinggi pada bahan organik ampas tahu dan dedak dapat dijadikan sebagai sumber nitrogen yang mampu dimanfaatkan mikroorganisme, kemudian mkroorganisme tersebut menjadi sumber makanan bagi Daphnia sp. Sehingga dapat disimpulkan bahwa unsur nitrogen yang terdapat pada protein dapat mempengaruhi pertumbuhan Daphnia sp. (Nainggolan, 2017).

Penggunaan ampas tahu dan dedak yang dimanfaatkan sebagai pakan dalam kultur Daphnia sp. sangat cocok karena nilai protein yang terdapat pada kedua bahan organik tersebut dapat memenuhi kebutuhan nutrisi dari Daphnia sp.. Menurut Nuraini (2009), ampas tahu mengandung protein kasar $27,55 \%$, lemak $4,93 \%$, dan serat kasar 7,11\%, Sedangkan menurut Setiawan (2017) dedak mengandung protein kasar 11,9-13,4\%, dan serat kasar $10-16 \%$. Selain itu proses fermentasi pada pakan ampas tahu dan dedak dapat mengurai pakan serta dapat meningkatkan nilai energi termetabolis agar lebih mudah dicerna oleh Daphnia sp. Pupuk organik ampas tahu dan dedak yang didekomposisi mempercepat proses dekomposisi sehingga dapat menumbuhkan bakteri yang nantinya bakteri inilah yang akan dimanfaatkan oleh Daphnia sp. sebagai pakan. Banyaknya jumlah bakteri dalam fermentasi tersebut dapat memenuhi kebutuhan makanan bagi Daphnia sp. sehingga meningkatkan laju pertumbuhan populasi.

Rendahnya pertumbuhan populasi pada perlakuan $\mathrm{D}$ dibandingkan dengan perlakuan $\mathrm{B}, \mathrm{C}$ dan $\mathrm{A}$ disebabkan karena jumlah $\mathrm{C} / \mathrm{N}$ rasio pada dedak tinggi yaitu 56:1 sehingga jumlah nitrogen rendah yaitu $0,69 \%$. Semakin tinggi $\mathrm{C} / \mathrm{N}$ rasio menunjukkan bahwa kandungan $\mathrm{N}$ yang rendah, dimana mikroorganisme pada probiotik EM4 memanfaatkan nitrogen untuk sintesis protein (pembentukan selsel tubuhnya) sehingga memicu pertumbuhan mikroorganisme dengan cepat dan mikroorganime pula akan dimanfaatkan oleh Daphnia sp. sebagai sumber makanannya (Suswardany, 2006).

\section{Produksi Biomassa Daphnia sp.}

Menurut Krettiawan (2011), menyatakan bahwa perbedaan jumlah populasi pada saat panen tentu berkaitan erat dengan kandungan nutrisi dari pakan yang diberikan. Hasil terbaik didapatkan pada perlakua B (ampas tahu dan dedak), namun tidak berbeda nyata dengan perlakuan C (ampas tahu), dan D (dedak). Hal ini disebabkan karena banyaknya pakan yang terserap oleh Daphnia sp. 
Jurnal Perikanan (2019) Volume 9. No. 1 : 101-111

DOI : https://doi.org/10.29303/jp.v8i2.138

sehingga didapatkan total bobot biomassa yang lebih banyak dibandingkan dengan perlakuan A.

Rendahnya produksi biomassa Daphnia sp. pada perlakuan A (pakan komersil), Hal ini dikarenakan karena Daphnia sp. tidak mendapatkan makanan dan tidak dapat mempertahanan hidupnya dan mati. Oleh sebab itu jumlah bobot biomassa pada perlakuan A lebih sedikit dibandingkan dengan perlakuan $\mathrm{B}, \mathrm{C}$, dan D yaitu sebesar 256,67 mg/l. Peningkatan bobot biomassa Daphnia sp. selain dipengaruhi oleh makanan juga dapat dipengaruhi oleh ukuran dan umur Daphnia sp. itu sendiri. Sitohang (2012) dalam Nailulmuna (2017), menyatakan bahwa fungsi makanan memiliki peran penting sebagai nutrisi dalam pertumbuhan biomassa Daphnia sp. dimana berbagai aktifitas kimiawi dan fisiologis terjadi didalam tubuh individu Daphnia sp. seperti pertumbuhan ukuran panjang, berat, dan pergantian kulit.

\section{Analisis C/N Rasio}

Tabel 5 menunjukkan bahwa $\mathrm{C} / \mathrm{N}$ rasio bahan organik ampas tahu dan pakan komersil kurang efektif untuk proses pengomposan. Rasio $\mathrm{C} / \mathrm{N}$ dedak terlalu tinggi menyebabkan mikroba akan kekurangan $\mathrm{N}$ untuk sintesis protein. Menurut Suswardany et al. (2006), C/N rasio yang rendah dapat menunjukkan kandungan $\mathrm{N}$ yang lebih tinggi. Hal ini dapat dilihat dimana pada pakan komersil mengandung $\mathrm{C} / \mathrm{N}$ rasio yang paling rendah 9:1, diikuti oleh ampas tahu dan yang paling tinggi pada dedak mengandung $\mathrm{C} / \mathrm{N}$ rasio sebesar 56:1. Menurut Pursetyo et al., (20011), N-organik dan C-organik dibutuhkan untuk pertumbuhan bakteri. Nilai N-organik yang rendah dapat menyebabkan jumlah bakteri pada media relatif rendah karena kebutuhan pakan bakteri rendah sehingga jumlah makanan yang dimakan oleh Daphnia sp. sedikit.

Tabel 5. Hasil C/N - Ratio

\begin{tabular}{ccccc}
\hline No. & $\begin{array}{c}\text { Kode } \\
\text { Sampel }\end{array}$ & $\%$ N & $\%$ C & $\begin{array}{c}\text { C/N- } \\
\text { Ratio }\end{array}$ \\
\hline
\end{tabular}

\begin{tabular}{lllcc}
\hline 1. & Ampas & 2,74 & 37,95 & $14: 1$ \\
& Tahu & & & \\
2. & Dedak & 0,69 & 38,47 & $56: 1$ \\
3. & Pakan & 4,68 & 42,07 & $9: 1$ \\
& Komersil & & & \\
\hline
\end{tabular}

Sumber : Hasil uji $\mathrm{C} / \mathrm{N}$ di Laboratorium Analisis Fakultas MIPA (2018)

Menurut Suswardany (2006), Kelebihan $\mathrm{N}$ ini biasanya akan dibuang dalam betuk gas $\left(\mathrm{NH}_{3}\right)$, terutama bila pengomposan berada pada suhu tinggi dan $\mathrm{pH}$ tinggi serta fosfor yang cukup pula. Namun, dalam penelitian ini dilakukan penambahan mikroorganisme (EM4) maka nitrogen yang terlalu tinggi justru akan dimanfaatkan oleh mikroorganisme yang ada sehingga memicu pertumbuhan mikroorganisme dengan cepat dan dapat mempercepat proses pengomposan.

\section{Perhitungan Jumlah Bakteri}

Banyaknya jumlah bakteri pada perlakuan B disebabkan karena semakin tinggi bahan organik dalam media pemeliharaan maka akan meningkatkan jumlah bakteri dan partikel organik hasil dekomposis oleh bakteri. Hal ini menunjukkan proses dekomposis bahan organik akan menumbuhkan banyak bakteri yang merupakan salah satu jenis makanan bagi Daphnia sp. Dekomposis merupakan proses pelapukan atau perombakan bahan organik secara biologis oleh mikroba dekomposer (probiotik) yang akan menghasilkan hara makro, mikro, hormon, vitamin, dan zat tumbuh. Selain itu penambahan bakteri dekomposer juga dapat mempercepat pelapukan bahan organik (Zahidah, 2012).

Bakteri probiotik yang digunakan dalam proses fermentasi berupa bakteri asam laktat (Lactobacillus caesai dan Saccharomyces cerevisiae) yang memiliki peran dalam meningkatakan percepatan perombakan bahan organik, dapat mengancurkan bahan-bahan organik. Bakteri Saccharomyces berfungsi 
Jurnal Perikanan (2019) Volume 9. No. 1 : 101-111

DOI : https://doi.org/10.29303/jp.v8i2.138

membentuk zat anti bakteri dan bermanfaat bagi pertumbuhan dari asam amino dan gula yang dikeluarkan oleh bakteri fotosintesis (Yunawati et al., 2012).

\section{Pengukuran Kualitas Air}

Petumbuhan dan perkembangan Daphnia sp. selain dipengaruhi oleh pakan yang diberikan juga dipengaruhi oleh faktor kualitas air media hidup Daphnia sp. misalnya suhu, oksigen terlarut (DO) dan pH. Nilai kualitas air pada penelitian ini masih pada taraf yang optimal sehingga dapat mendukung pertumbuhan populasi Daphnia sp. yaitu suhu $29,7-30^{\circ} \mathrm{C}$. Menurut Mubarak et al (2009), kisaran suhu yang toleransi bagi pertumbuhan dan perkembangan Daphnia sp. berkisar antara $25-30^{\circ} \mathrm{C}$.

Oksigen terlarut pada masingmasing perlakuan media pemeliharaan Daphnia sp. selama penelitian berkisar antara 4,2-5,9 mg/l. Menurut Purba (2003), oksigen terlarut yang baik untuk pemeliharaan Daphnia sp. yaitu berkisar antara $0,34-7,7 \mathrm{mg} / \mathrm{l}$. Nilai $\mathrm{pH}$ pada media pemeliharaan berkisar antara 7-7,8. Menurut Pennak (1989) dalam Sulasingkin (2003), pH yang baik dalam pemeliharaan Daphnia sp. berkisar antara 6,5-8,6.

\section{Kesimpulan}

Berdasarkan hasil penelitian yang diperoleh dapat disimpulkan bahwa kombinasi fermentasi ampas tahu dan dedak berpengaruh nyata $(\mathrm{p}<0,05)$ terhadap pertumbuhan populasi Daphnia sp. Kombinasi hasil fermentasi ampas tahu dan dedak yang memberikan pertumbuhan tertinggi yaitu pada perlakuan $\mathrm{B}(0,15 \mathrm{~g} / \mathrm{l}$ ampas tahu dan 0,3 g/l dedak) dengan kepadatan puncak populasi 246,67 ind/1 dan laju pertumbuhan populasi $5,199 \%$ /hari dengan pertambahan populasi setiap 2 hari yaitu 106,67 ind/l, $173,33 \mathrm{ind} / 1$ dan $246,67 \mathrm{ind} / 1$.

\section{Daftar Pustaka}

Aji, W.K. 2015. Pengaruh Penambahan EM4 (Effective Microorganisme-4) Pada Pembuatan Biogas dari Enceng Gondok dan Rumen Sapi. Fakultas Teknik. Universitas Negeri Semarang.

Astawan, M., dan Febrinda, A. E. 2010. Potensi Dedak dan Bekatul Beras Sebagai Ingredient Pangan dan Produk Pangan Fungsional. Artikel Pangan 14, 19 (1).

Boyd, C.E. 1982. Water Quality Management for Pond Fish Culture. Elsevier Scientific Publising Company, Amsterdam. 17 p.

Carvalho, G.R. and R.N. Hughes. 1983. The effect of food availability, female culture- density, and photoperiod on ephippia production in Daphnia magna Straus: (Crustacea: Cladocera). Freshwater Biology 13(1):37-46.

Casmuji. 2002. Penggunaan Supernatan Kotoran Ayam dan Tepung Terigu Dalam Budidaya Daphnia sp.. Skripsi. Fakultas Perikanan dan Ilmu Kelautan. Institut Pertanian Bogor.

Fajri M. A., Adelina dan Aryani N. 2015. Penambahan Probiotik Dalam Pakan Terhadap Pertumbuhan dan Efisiensi Pakan Benih Ikan Baung (Hemibagrus nemurus). Jurnal Fakultas Perikanan dan Ilmu Kelautan, Universitas Riau.

Goldman, C.R. and A.J. Horne. 1983. Limnology. McGraw-Hill International Book Co., Tokyo. p: 464.

Herawati, V.E, M. Agus. 2013. Analisis pertumbuhan dan kelulushidupan larva lele (clarias gariepenus) yang diberi pakan daphnia sp. hasil kultur massal menggunakan pupuk organik difermentasi. Fakultas Perikanan dan Ilmu Keluatan. Universitas Diponegoro.

Ivleva. 1973. Mass Cultivation of Invertebrates: Biology and Methods. Transi. by A. Mercado. Academic of Sciences on the U.S.S.R. All 
Jurnal Perikanan (2019) Volume 9. No. 1 : 101-111

DOI : https://doi.org/10.29303/jp.v8i2.138

Union Hydrobiologycal Society, Jerussalam.

Izzah N dan Herawati V.E. 2014. Pengaruh Bahan Organik Kotoran Ayam, Bekatul, dan Bungkil Kelapa Melalui Proses Fermentasi Bakteri Probiotik Terhadap Pola Pertumbuhan dan Produksi Biomassa Daphnia sp. Jurnal Manajemen Perikanan dan Teknologi, 3 (2):44-52.

Jaelani A, Piliang G.W, Suryahadi, dan Rahayu I. 2008. Hidrolisis Bungkil Inti Sawit (Ellaeis guineesis, Jacq) Oleh Kapang Trichoderma reesei Pendegradasi Polisakarida Manan. Animal Production, 10 (1): 42-49.

Kusmaryanto, H. 2001. Pengaruh Jumlah Inokulasi Awal Terhadap Pertumbuhan Populasi, Biomassa dan Pembentukan Epipium Daphnia sp. Fakultas Perikanan, Institut Pertanian Bogor.

Mokoginta, I. 2013. Budidaya Pakan Alami Air Tawar. Modul Daphnia sp. Direktorat Pendidikan Menengah Kejurusan-Ddikdasmen Depdiknas.

Ninggar, M. W. 2016. Pengaruh Pemberian Dosis Pupuk Dari Air Endapan Campuran Kotoran Ayam dan Dedak Terhadap Pertumbuhan Populasi Daphnia magna. Skripsi. Program Studi Pendidikan Biologi, Fakultas Keguruan dan Ilmu Pendidikan, Universitas Santana Dharma Yogyakarta.

Nurjannah, Sutaman, dan Dwi Wiwaraning Tyas. 2007. Pengaruh Fermentasi Dedak denagn Dosis Peragian Yang Berbeda Terhadap Pertumbuhan dan Kelangsungan Hidup Ikan Nila Merah (Oreochromis niloticus) Pada Pendederan II. Cermin Edisi 041.

Nuraini, Sabrina dan Suslina A. Latief. 2007. Improvingthe Quality of Tapioka by Produck Thurgh Fermentation by Neurospora Crasato Produce $\beta$ Carotene Rich Feed. Pakistan Journal of Nutrition. 8 (4).
Nuraini, S.A. Latif, dan Sabrina. 2009. Potensi monascus pupureus untuk membuat pakan kaya karotenoid dan aplikasinya untuk memproduksi telur unggas kolestrol. Working Paper. Fakultas Peternakan

Pankey, H. 2009. Daphnia dan Penggunaannya. Jurnal Perikanan dan Kelautan, V (3).

Purti, E.Y, Pamukas A. N, dan Hasibuan S. 2015. Influence giving rice bran immersion at chicken Manure media on the abundance daphnia magna. Fisheries and Marine Science Faculty, Riau University.

Rakhman. E, Hamdani. H dan Gunawan, S. 2012. Pengaruh Urine Kelinci Hamil Dalam Media Kultur Terhadap Kontribusi Anak Setiap Kelompok Umur Daphnia spp.. Jurnal Perikanan dan Kelautan. 3(3).

Rasyaf, M. 2004. Seputar Makanan Ayam Kampung, Cetakan ke-8. Yogyakarta : Kanisius.

Septiyani, S. 2013. Pemanfaatan Limbah Ampas Tahu Sebagai Bahan Baku Pembuatan Pupuk Organik Cair (POC). [Skripsi]. Jurusan Manajemen Pertanian, Politeknik Pertanian Negeri Samarinda.

Simamora, S dan Salundink. 2008. Meningkatkan Kualitas Kompos. PT. AgroMedia Pustaka, Jakarta.

Sukaryana, Y. 2011. Peningkatan Nilai Kecernaan Protein Kasar dan Lemak Kasar Produk Fermentasi Campuran Bungkil Inti Sawit dan Dedak Padi Pada Broiler. JITP. 1 (3).

Sulasingkin, D. 2003. Pengaruh Konsentrasi Ragi Yang Berbeda Terhadap PertumbuhanPopulasi Daphnia sp. Skripsi. Fakultas Perikanan dan Ilmu Kelautan, Institut Pertanian Bogor.

Yulianingrum, T, Pamukas A.N, dan Putra I. 2016. Pemberian Pakan Yang Difermentasikan Dengan Probiotik Untuk Pemeliharaan Ikan Lele Dumbo (Clarias gariepinus) Pada 
Jurnal Perikanan (2019) Volume 9. No. 1 : 101-111

DOI : https://doi.org/10.29303/jp.v8i2.138

Teknologi Bioflog. Jurnal Jurusan Budidaya Perairan, Fakultas Perikanan dan Ilmu Kelautan, Universitas Riau.

Yunda, p. D. 2015. Peningkatan Pertumbuhan Daphnia sp. Menggunakan Media Kotoran Ayam Yang Dicampur Dedak Padi Dengan Konsentrasi Berbeda. [Skripsi]. Fakultas Matematika dan Ilmu Pengetahuan Alam, Universitas Lampung.
Widarti, N.B, Wardhini K.W, dan Sarwono E. 2015. Pengaruh Rasio C/N Bahan Baku Pada Pembuatan Kompos Dari Kubis dan Kulit Pisang. Jurnal Integrasi Proses. 5 (2): 75-80.

Zahidah, 2012. Pertumbuhan Populasi Daphnia sp. Yang Diberi Pupuk Limbah Budidaya Keramba Jaring Apung (KJA) Di Waduk Cirata Yang Difermentasi EM4. Jurnal Akuatik. III(1): 84-94. 